\title{
PAUL STRAND'S LIVING LABOR
}

The kettle began it. . . .

CHARLES DICKENS, QUOTED BY SERGEI EISENSTEIN ${ }^{1}$

\section{FORMALISM}

In I92I, Paul Strand put down his still camera and began work on his first film, Manhatta. Produced in collaboration with the painter and photographer Charles Sheeler, the film runs just under ten minutes. It runs from dawn to dusk, following a day in the life of New York City, the film's protagonist. The film's main "players" include the iron and marble facades of the city's soaring architecture, the Hudson River, and smoke. Its main focus is movement. Opening with a long shot of the New York skyline, Manhatta quickly turns our perspective on the city ninety degrees. High-angle shots survey the changing shapes of clouds and steam, suited men and women hurrying off a ferry and streaming across Lower Manhattan, and water. In I92I, Strand and Sheeler put down their still cameras in order to make their city move.

Strand and Sheeler's moving image restaged several of Strand's still photographs. The most recognizable is Strand's iconic shot of suited New Yorkers walking to work in front of the ominous black

I Sergei Eisenstein, "Dickens, Griffith and Film Today," in Film Form: Essays in Film Theory, ed. and trans. Jay Leyda (New York: Harcourt, Brace \& World, I949), I95. 
photographic practice? Should we study these media separately? Or, more to the point, what kinds of histories necessitate the distinction between film and photography?4 Perhaps it is the history of photography that Strand offered us in I9I7. As he explained that year in a two-page screed published in the little magazine Seven Arts, "Photography, which is the first and only important contribution, thus far, of science to the arts, finds its raison d'être, like all media, in a complete uniqueness of means." ${ }^{5}$ Unabashedly pitched against those photographers who muddied photography with "hand work" - dyes, daubs of paint, and etching-Strand defined photography's uniqueness of means as "an unqualified objectivity." ${ }^{\prime 6} \mathrm{He}$ historicized photography against art's "dead things" and branded himself a formalist. ${ }^{7}$ This is a history of photography, which, as countless critics of Strand and formalism have argued, conveniently disassociates the image maker from the social embeddedness of the image. "Pure" or "straight" photography, like the still photographs restaged in and reproduced from Manhatta, amounted to what the art critic Clive Bell called "significant form." Form, as Bell defined it, exists prior to its embodiment in matter, and "uniqueness of means" is thereby abstracted from any investigation of the means of production. ${ }^{9}$ Strand's investigation of photography through film has been conveniently eclipsed. His photography is thought through (or against) painting and Strand's fascination with pure form.

Yet, Strand's examination of photography through film was not a passing fad. In his second major film, Redes or The Wave, he continued to investigate the relationship between stasis and movement. Shot in I934 under the auspices of Mexico's Secretariat of Public Education, The Wave bears little resemblance to Manhatta. It is a film about land,

4 Bazin's writing also frames most attempts to answer this question. See Jan-Christopher Horak, Making Images Move: Photographers and Avant-Garde Cinema (Washington, DC: Smithsonian Institution Press, I997), I-27, and David Campany, Photography and Cinema (London: Reaktion Books, 2008).

5 Paul Strand, "Photography," in Photographers on Photography, ed. Nathan Lyons (Englewood Cliffs, NJ: Prentice Hall, I966), I36. "Photography" was reprinted in the final issue of Camera Work, which Stieglitz dedicated solely to Strand's work.

$6 \quad$ Ibid. On "hand work," see Alfred Stieglitz's I899 "Pictorial Photography," in Photography: Essays Q Images: Illustrated Readings in the History of Photography, ed. Beaumont Newhall (London: Secker \& Warburg, I981), I63-66.

7 Strand, "Photography," I36.

8 This reading paraphrases Allan Sekula's now classic essay examining the limits of formalism and modernist histories of photography, "On the Invention of Photographic Meaning," Artforum I3, no. 5 (January i975): 36-45.

$9 \quad$ On Bell's formalism and its limits, see Yve-Alain Bois, "Whose Formalism?," Art Bulletin 78, no. I (March 1996): 9-12. 


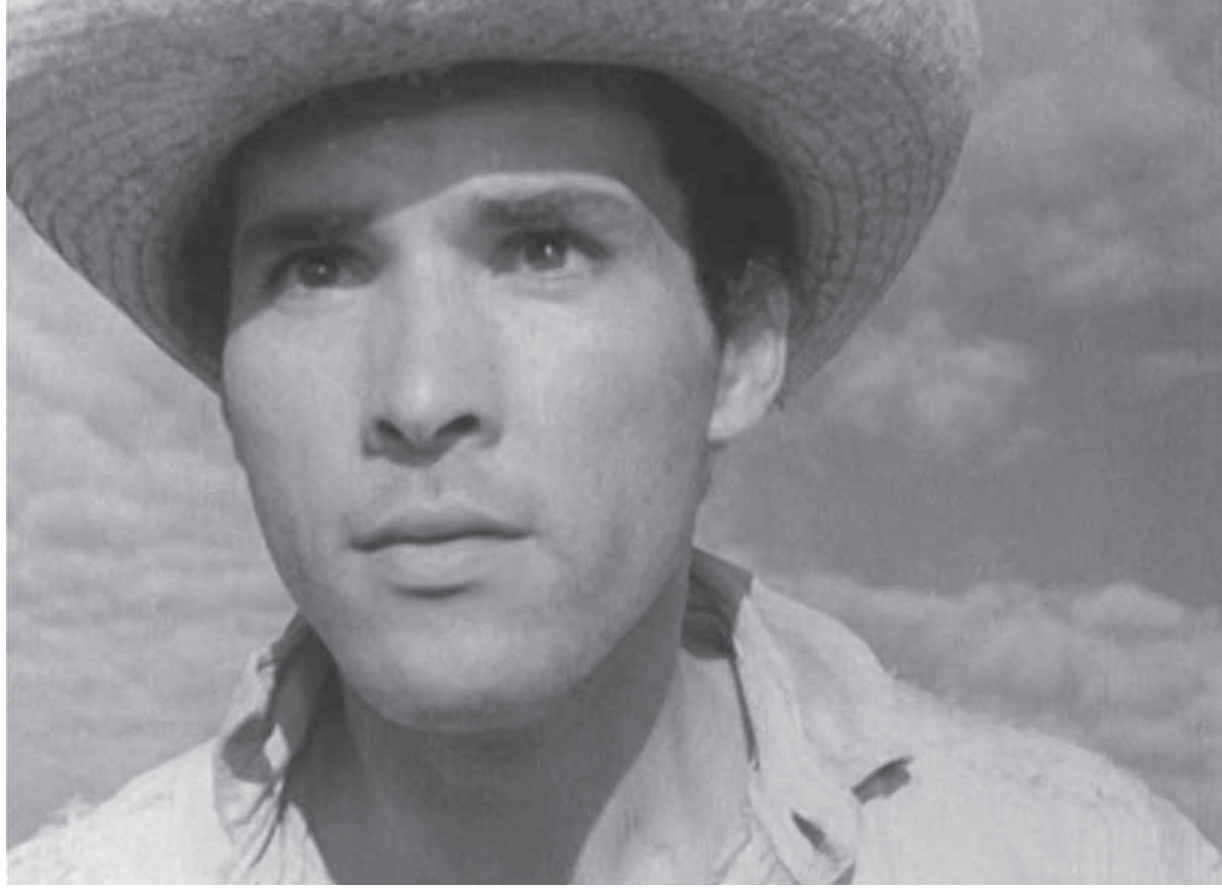

Fred Zinnemann, director. The Wave, 1936. Frame.

not the city. It is a film about people and work. If in Manhatta workers rush along the street diminished by the city's soaring architecture and the camera's aerial approach, in The Wave they are shot straight on, close-up, and loom larger than life. The Wave, in fact, is punctuated by close-up shots of the faces of the fishermen Strand hired to act out a story about labor struggles in postrevolutionary Mexico. The faces of the impoverished fishermen intermittently fill the film frame, stopping action and reminding us of the series of close-up and tightly cropped portraits Strand produced in Lower Manhattan in I9I6. The resemblance between the faces of New York's public - the newspaper seller, the sandwich man, the "dandy" in his bowler hat, to name a few of Strand's subjects - and Mexico's peasants was not lost on the film's reviewer. When The Wave premiered in New York at the Filmarte Theatre in 1937 several noted that the film was slow, sluggish, and not much more than an "interesting photographic album." ${ }^{10}$ Sergei Eisenstein offered a similar response to The Wave when Strand visited the Soviet filmmaker in I935 hoping to collaborate on Eisenstein's next production. ${ }^{11}$ In 1934 , Strand stopped making still photographs.

Io See photocopies and scrapbook clippings in the Paul Strand Collection, Center for Creative Photography, University of Arizona, Tucson, AG I7:28/13 (hereafter PSA/CCP).

II The collaboration never came to fruition, nor did the proposal that Strand work for The USSR in Construction. See PSA/CCP, Finding Aid. 
He worked in film until I942 and turned the Soviet master into his new mentor. Holding a few clips of The Wave up to the light, Eisenstein told Strand, "Well, I can see that you are a still photographer, not a film photographer."12

What are we to make of Eisenstein's response to The Wave? Had Strand failed as a filmmaker? Did he fail to make images move? Is this film's raison d'être? Since the I920s, Eisenstein had been arguing that film is not defined by the movement of images on the screen or in accordance with its technology. Film, Eisenstein insisted, does not move images; it moves the audience "in a desired direction." 13 The doyen of Soviet cinema, in short, eschewed

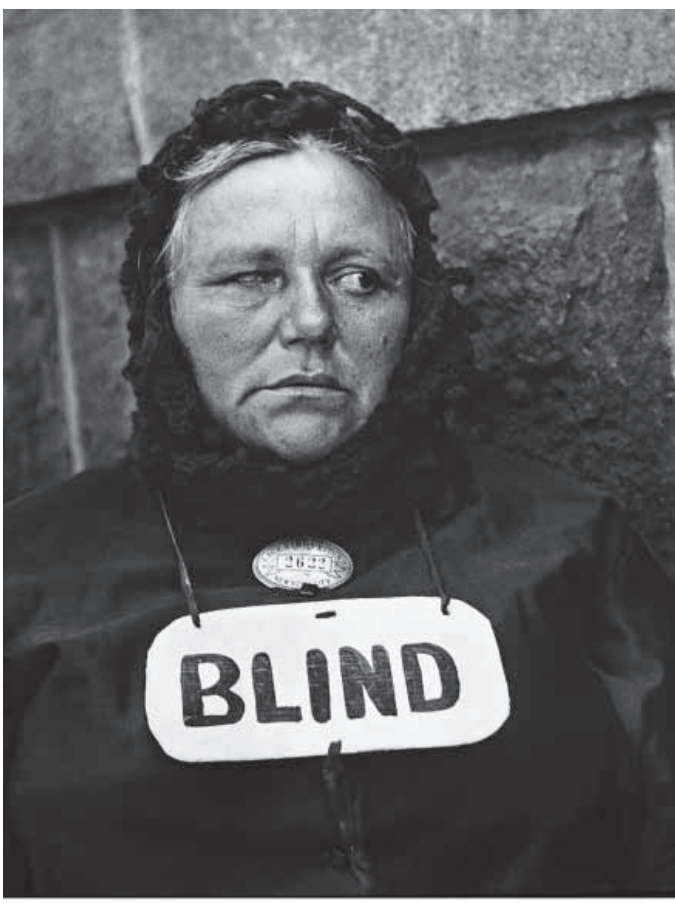

EW-POR-009

Paul Strand. Photograph-New York, 1917, 1917.

(C) Aperture Foundation Inc., Paul Strand Archive. conventional investigations of media ontology in order to examine the social machine..$^{14}$ Eisenstein's response to The Wave, then, compels us to rethink our assumptions about the relationship between film and photography as well as our assumptions about Strand's formalism. The question posed by The Wave — and Manhatta - is not why Strand turned to film. It is why we have insisted on separating Strand's interrogation of media from his direct engagement with politics and revolution. Posed differently, is Strand the formalist we want or need him to be?

I2 Strand recounted this conversation to Milton Brown in I97I. "Tape recorded interview with Paul Strand by Milton Brown, under the auspices of the Archives of American Art," PSA/CCP, AG I7:37/I.

I3 Eisenstein, "The Montage of Attractions," in The Eisenstein Reader, ed. Richard Taylor, trans. Richard Taylor and William Powell (London: British Film Institute, I998), 35.

I4 See Jean-Louis Comolli's examination of film as a social machine as well as his critique of Bazin in "Machines of the Visible," in The Cinematic Apparatus, ed. Teresa de Lauretis and Stephen Heath (New York: St. Martin's, I980), I2I-42. 
Strand's formalism has certainly left an indelible mark on our histories of Strand and photography's development in the United States. He is simultaneously the "perfect" modernist—radically asocial—and a representative of the bankruptcy of modernism's unmotivated assessment of the relationship between man and technology. Yet, if Strand conveniently occupies both positions in our histories of modernism, it is not because he recognized — and pursued — the distinction between modernist interrogations of media and the social qualities of the message. It is because he displaced it through an examination of one specific form: the human face. Like Eisenstein's, Strand's commitment to objectivity was never medium specific. His medium, in fact, was neither film nor photography. It was portraiture.

\section{ROMANCE OF REVOLUTION}

The Wave certainly surprised audiences at New York's Filmarte Theatre in I937. Shot on location in a small fishing village and with nonprofessional actors, The Wave lacked the avant-garde flair of the skewed perspectives of Manhatta and Strand's still studies of the city's new and magnificent forms. In I934, Strand traded in his oblique approach to New York's movement for a slow and steady look at the country. Moreover, unlike Manhatta, which lacked a plot and a hero, The Wave was a narrative film. It had a story, a protagonist—a fisherman named Miro - and a moral. It also had a soundtrack and dialogue. Opening on the shore with a series of close-up shots of Miro fishing, The Wave reworked the classic tale of man versus nature into a history lesson about the economic logic of capital and labor's alienation. Miro's failure to eke a livelihood out of the sea-he pulls one fish from the wake in the film's first scene-culminates in his decision to gather the local fishermen at the dunes and call for strike action. Not all of the fishermen agree with Miro's plan, and a fight breaks out between the strikers and the scabs, resulting in Miro's murder at the hands of a smoothtalking politician. The film closes at sea with renewed efforts by those fishermen once doubtful of Miro's insistence that "poverty is not the fault of nature, nor God's Law," the closing lines of his call to arms, finally to rise up against capitalism. No one missed the film's message. As the editors of Life magazine noted in the four-page spread on Strand's Mexican adventure, which was accompanied by film stills of weathered men at work, "The virtue of the film as propaganda lies in its simple demonstration that workers must organize. This is a lesson 
which the anti-capitalist government of Mexico is very anxious to din into the minds of the long-oppressed workers and peasants." ${ }^{15}$ In Mexico, Strand, so it seemed, relinquished form and modernism for politics and propaganda.

The accusation of propagandism was not far off. In addition to shooting the film and working with local fishermen and government officials to write the scenario, Strand was appointed director of the Secretariat's Office of Photography and Cinematography and asked to oversee a program of educational films (Plan para la filmación de peliculas educativas) that could compete with the melodramas about the revolution on offer from the Hollywood-inspired film docket. ${ }^{16}$ The Wave was the first and only film completed in what became known as the Secretariat's "Five Year Film Plan." Self-consciously styled after the Soviet economic program, the plan responded directly to the previous administration's insistence that cinema was a "typically US cultural product," and one that was "impossible to develop as a national form." ${ }^{17}$ Until the I930s, the mural, not film, had been pitched as the medium for shaping political consciousness and collective action. The Secretariat's new agenda was certainly influenced by another foreigner-Eisenstein. Eisenstein's own Mexican adventure and his failure to complete his epic ¡Qué Viva Mexico! in I93I sparked an interest in the revolutionary potential of film. It also framed Eisenstein as a national hero. Touted el magnifico in the Mexican press, Eisenstein was one among many foreigners, including Tina Modotti and Edward Weston, who, as Alfonso Morales Carrillo has noted, validated Mexico's modernity (modernidad) and mitigated the country's "inferiority complex." 18

I5 “American Photographer Does Propaganda Movie for Mexico," Life 2, no. I9 (May Io, I937): 62-65. A Post review similarly described The Wave as simple, referring to it as "Lesson Number One in the organization of labor, a kindergarten lesson in class struggle." See PSA/CCP, AG I7:7/3.

I6 Strand developed the scenario in consultation with Agustín Vélazquez Chávez and a failed call for local filmmakers to provide a compelling screenplay. James Krippner analyzes Strand's negotiations with the Secretariat in Paul Strand in Mexico (Mexico City: Fundación Televisa/Aperture Foundation, Distributed by D.A.P., 20I0), 69-95.

I7 José Vasconcelos, quoted in Andrea Noble, Mexican National Cinema (Abingdon: Routledge, 2005), 3I.

I8 Alfonso Morales Carrillo, "Spanish for Your Mexican Visit: Paul Strand South of the Border," in Krippner, Paul Strand in Mexico, 239-62. On the complexities of Eisenstein's reception, specifically accusations that his film promoted "stereotypical clichés," see Noble, Mexican National Cinema, I29-39. 
Outlined in his "A Note on Cine," a five-page prospectus for the Plan, Strand's program directly addressed the relationship between film and the nation. ${ }^{19}$ How, he asked, would the Secretariat ensure that the films speak to the audience for which they were intendedMexico's sixteen million illiterate peasants? ${ }^{20}$ Strand did not find his answer in Mexico. He found it in film. His "Note" opened with a nod to Soviet filmmaking and anticapitalist propaganda. Moving pictures, Strand insisted, were a "powerful social instrument," one that had been perverted by the medium's "most destructive and corrupt form," Hollywood film. ${ }^{21}$ Hollywood productions were "the opiate of the people," Strand explained; they were a means of inculcating "false values" by "exploiting the public's sadistic interest in all kinds of . . . sugarcoated sex perversities."22 Strand's "Note" did not outline a film program. It outlined the ways in which filmmakers had responded to the philistinism of commercial film. Strand moved through Soviet, French, German, and North American examples-from Eisenstein through Charlie Chaplin and Robert Flaherty_-searching for a model for the Mexicans to follow. What the Mexicans needed, Strand surmised, was not an indigenous film school. They needed to understand the history of film. Illiteracy, in other words, was not simply the inability to read and write. It was ignorance about industrial means of propaganda or the political linguistics of the picture.

Strand's bureaucratic efforts followed suit. In conjunction with his prospectus, he hired Henwar Rodakiewicz and Fred Zinnemann to direct The Wave and train a new generation of Mexican filmmakers. ${ }^{23}$

I9 Publicity cards distributed in Mexico read as follows: "iiVerdadera Justicia Social!! Es la claman los de 'abajo' y los de 'enmedio.' 'Redes' La primer pelicula de ambición estética nacional le dirá como alcanzarla. ¡Una Verdadera Pelicula Nacional!” (Social Justice is the cry of those from below and those in the middle. Redes, the first film of national aesthetic ambition, will tell you how to achieve it.) Translation mine. Reprinted in Krippner, Paul Strand in Mexico, 9 .

20 See Strand, interview with Peggy Farber, June 26, I974, n.p., PSA/CCP, AG 17:7/9. See also the transcript from Strand's presentation of The Wave to the members of the Photo League in I947. “'The Wave,'” Photo Notes, August-September I947, 5, reprinted in Photo Notes, February 1938-Spring 1950/Filmfront, December 1934-March 1935 (Rochester, NY: Visual Studies Workshop, I977).

2I Strand, "A Note on Cine," quoted in John Rohrbach, "Art for Society's Sake: Paul Strand's Photographic Vision" (PhD diss., University of Delaware, I993), II8. Strand never published his "Note," and it is no longer among his papers at the CCP.

22 Strand, quoted in Rohrbach, "Art for Society's Sake," iा8.

23 When Rodakiewicz was called away to another film, he urged Strand to recruit Zinnemann, who had recently worked with Flaherty in Berlin. Notably, Zinnemann complained that the film lacked movement and that Strand was not a competent filmmaker. See Fred Zinnemann, An Autobiography (London: Bloomsbury, I992), 3I-37. 
The educational matrix of the program, in short, was not limited to the "simple" message of the film. It amounted to a re-education of Mexico's cultural workers. Accordingly, Strand supplemented technical training with international film screenings. The list of films shown in Mexico is unknown, though we do know some of what Strand might have included. In I933, he wrote to his close friend, the playwright Harold Clurman, and asked him to recommend a selection of films that might "speak" to the Mexican audience. Clurman suggested the latest Soviet, German, and French productions that had been circulating in the United States among the left-leaning art audience. These included Alexander Dovzhenko's Ivan (I932), René Clair's Freedom for Us (I93I), Slatan Dudow's Wither Germany or Who Owns the World? (I932), which was written by Bertolt Brecht, and Yakov Protazanov's An Hour with Chekhov (I933). ${ }^{24}$ Showcasing a range of genres and storylines - from Clair's comedy about the mechanization of work to Dudow's documentary about unemploymentStrand's call for a program addressing local concerns found its footing in a decidedly Soviet-style call for the international radicalization of mass media.

Strand's work in Mexico evidences more than a commitment to film or a new commitment to politically engaged subject matter-collectivization, labor struggles, and strikes. It evidences a commitment to developing a new means for organizing publics. Strand's program in this regard did not develop in Mexico or through the Secretariat's nationalist agenda. Strand took his lead from Clurman. Clurman advised Strand on the "revolutionary effectiveness" of the film's scenario, which he argued depended on drawing out the dialectical relationship between Miro's plight and the plight of the community of fishermen. ${ }^{25}$ He also provided Strand with a working method. Since the late I920s, the playwright had been dedicated to developing a new role for the audience in his theatrical productions. Clurman's efforts culminated in I93I with the founding of the New York theater troupe Group Theatre. Along with Cheryl Crawford and Lee Strasberg, Clurman set out to rival Broadway productions around a commitment to collective negotiations among writers, directors, actors, and the audience. ${ }^{26}$ Group Theatre, as one of their publicity memos explained, sought "to 
create an audience that will identify itself with and can become constructively active in Group's work." ${ }^{27}$ In their I93I manifesto "What Group Theatre Wants," Clurman enhanced this call for a new audience, explaining,

\begin{abstract}
When an audience feels that it is really at one with a theatre; when audience and theatre-people can feel that they are both the answer to one another, and that both may act as leaders to one another, there we have the Theatre in its truest form.
\end{abstract}

To create such a Theatre is our real purpose. ${ }^{28}$

Group Theatre's I935 production of Clifford Odets's Waiting for Lefty, a play loosely based on the February I934 New York taxi strike, succeeded on this front. Staged as a negotiation between union leaders and drivers, the performance culminated in the audience cheering and chanting "Strike, Strike!” The fourth wall had been broken; or, as Odets commented following the play's final performance, "the proscenium arch had disappeared." 29

Strand was a member of Group Theatre. ${ }^{30}$ He also helped found Group Associates, a subsidiary organization of playwrights, filmmakers, writers, and photographers eager to support Group Theatre's agenda. ${ }^{31}$ Appositely, The Wave was billed by several of

27 “The Group Theatre ... Audience ..., , PSA/CCP, AG I7:I4/I4. This publicity memo included Group Theatre's sixteen-point memorandum on direction, organization, audience, and finance, noting that each play would culminate with the submission of comments from the audience to be considered in meetings between Group Theatre and the audience during the run of the play.

28 Clurman, Fervent Years, 72.

29 Odets, quoted in Margaret Berman-Gibson, Clifford Odets, American Playwright: The Years 1906-1940 (New York: Atheneum, I98I), 315-I6.

30 Clurman to Strand, September 24, I93I, PSA/CCP, AG I7:I4/I4. Clurman invited Strand to the first Group Theatre meeting and reminded him that he was part of the Group Theatre "family." Strand also recalled "[t]he Group Theatre was something in which I had been very much interested before going to Mexico. ... I had participated as a spectator in the development of the whole idea of that theatre." PSA/CCP, AG I7:37/I.

3I Strand to Clurman, Strasberg, and Crawford (on behalf of Group Associates), July 3, I936, PSA/CCP, AG I7:I2/4. Strand wrote, "We believe that the Group Theatre can be a nucleus around which, and through which, the other arts can be brought to new and important foci." Associate members included Ralph Steiner, Stieglitz, Waldo Frank, and Aaron Copland. Mike Weaver first outlined these associations in his article "Dynamic Realist," published in Paul Strand: Essays on His Life and Work, ed. Maren Stange (New York: Aperture, 1990), I97-208. 
the film's New York reviewers as a "Mexican Waiting for Left $y . "{ }^{2}$ Strand's socially engaged practice began in New York and with theater. He eschewed a commitment to media in order to address, as Clurman had, collective methods of production. The fishermen on the screen were both actors and audience. The "simple" message of The Wave, its propaganda, in short, exceeded its storyline-the economics of exploitation. It was located in a dynamic and complex rethinking of the labor of production and the collectivization of those watching the work. In this regard, The Wave was neither about nor necessarily for Mexico's peasants. It was an artifact of an internationalization of the left in the United States in the I930s. Strand's "romance of revolution," to borrow Michael Denning's phrase for characterizing the work of those artists and writers traveling to Mexico and the Soviet Union in the I930s, manifests a profound transformation in US politics in the wake of the Depression: the organization of powerful mass social movements through a retooling of the cultural industry. ${ }^{33}$ Strand's move to the margins, though, was not a move back to the center. If The Wave refracted the limits of leftist politics in the United States, it did so by engaging the ways in which the radicalization of mass media might explode these geopolitical binaries.

\section{MOVING THE AUDIENCE}

Strand was certainly not alone in his bid, as Eisenstein once put it, to move "through theater to cinema." ${ }^{4}$ In I935, two Group Theatre affiliates, Leo Hurwitz and Ralph Steiner, developed a film program around the insistence that the lessons of theater were the key to unsettling film audiences from their Hollywood-induced, opiate-like stupors. The duo outlined their program in "A New Approach to Filmmaking (An Article Based on a Report Given at the Conclusion of Lee Strasberg's Course)." Appearing in New Theatre, a major left-wing magazine dedicated to the latest international developments in theater, film, and dance, the article opened as follows: "With no film school in America led by an Eisenstein, we feel that the revolutionary moviemakers must go for help to theatre workers like Strasberg and others who thought deeply on the problems of

\footnotetext{
32 See, among others, the above-noted Post review (see footnote 15).

33 Michael Denning, The Cultural Front: The Laboring of American Culture in the Twentieth Century (London: Verso, I997), I2-I3.

34 Eisenstein, "Through Theater to Cinema," in Leyda, ed., Film Form, 3-I7.
} 
films." ${ }^{35}$ Strasberg's course mixed media. He deftly combined a reading of Eisenstein's films and Vsevolod Pudovkin's I926 study On Film Technique and Film Acting with a reworking of Constantin Stanislavski's system. A response to what the Moscow-based director called "mechanical acting," acting based on the representation of conventional gestures, Stanislavski's system trained actors to develop their roles through a recall to their own sensory experiences. This summoning of memory was meant to prompt "observable behaviors" in the actors that resonated with the plight of their character. ${ }^{36}$ There was a difference, Stanislavski argued, between the representation of emotions and the channeling of actors' "real" emotional response. Actors, as Strasberg argued in his course and through what he called his method, would no longer act. They would no longer, as on Broadway, find themselves alienated from their emotions. This, he argued, was "proletarian" theater. ${ }^{37}$

Steiner and Hurwitz looked to Strasberg's method to address the limits of commercial film productions. In Hollywood films, the duo argued, "the whole emphasis was on the beauty, the shock, the effectiveness of овJECTS, THINGS-with no analysis of an effect on the audience." ${ }^{38}$ Commercial film certainly provided technological advances; yet, as was the case with other means of mass industrialization, from assembly line production to urbanization, things, not people, reigned supreme. Film, they concluded, had become "inhumane" and "depersonalized." ${ }^{39}$ It shocked the audience, instead of moving them to act. Correcting this pervasive fetishization of film, Steiner and Hurwitz insisted, required more than the embrace of politically correct subject matter. It required rethinking film form through a theatrical engineer-

Ralph Steiner and Leo Hurwitz, "A New Approach to Filmmaking," in New Theatre and Film, 1934-1937: An Anthology from the Leading Left-Wing Arts Magazine of the Era, ed. Herbert Kline (San Diego: Harcourt Brace Jovanovich, I985), 30I. Translations of Eisenstein's, Vsevolod Pudovkin's, Ilya Ehrenburg's, and Sergei Tret'iakov's writing on film filled the pages of New Theatre.

36 On Stanislavski's system, see Timothy J. Wiles, Theater Event: Modern Theories of Performance (Chicago: University of Chicago Press, I980), I3-36, and Colin Counsell, Signs of Performance: An Introduction to Twentieth Century Theatre (New York: Routledge, I996), 24-5I.

37 Strasberg's method and what became known as method acting have been critiqued for producing the opposite effect, i.e., false consciousness. See Judith Rodenbeck, "Madness and Method: Before Theatricality," Grey Room I3 (Fall 2003): 6I-62.

38 Steiner and Hurwitz, "New Approach," 302.

39 Ibid. 
ing of audience response. "Unless," Steiner and Hurwitz explained, "this audience response is obtained, films, however profound and socially important in subject, will be lifeless and socially ineffectual." ${ }^{40}$ Theater work eclipsed the debate between form and content. It also mitigated the ontological differences between media. For Steiner and Hurwitz, theater was no different from film. It provided a new means for examining the principles behind their craft. That craft was not film per se; it was social revolution.

Steiner and Hurwitz's turn to theater and a call for the humanization of film was not solely directed against what they perceived to be the limits of commercial cinema. It was also directed against the documentary productions of the Workers Film and Photo League. Since I930, when the league emerged as the US division of the Workers International Relief, which was founded in I92I under the leadership of Willi Münzenberg, its members had been committed to the production of non-narrative documentary newsreels. This film form, they argued, redressed the distorted representations of workers on offer in the mainstream media. It also competed with them. "Films are being used against the workers like police clubs," wrote Samuel Brody, one of the league's founding members, on the pages of the Daily Worker in May I930, adding, "If the capitalist class fears pictures and prevents us from seeing records of events like unemployment demonstration[s] . . . we will equip our own cameramen and make our own films." ${ }^{41}$ Here, Brody outlined one of Münzenberg's most important lessons: workers cannot shy away from mass media since, as Münzenberg noted, "Forty years ago the bourgeoisie had already understood that the photographic picture has a very special effect on the spectator." ${ }^{42}$ Revolution had to be staged in mass media. It had to be staged through the very same means the bourgeoisie used to beat down its workers.

Countering mainstream media, in turn, did not mean exposing its lies. The league's newsreels provided more than new, different, or

\footnotetext{
40 Ibid., 30I.

4I Samuel Brody, quoted in Russell Campbell, "Film and Photo League: Radical Cinema in the 3os," Jump Cut I4 (I977): 23-25, accessed November 28, 20II, http://www.ejumpcut .org/archive/onlinessays/JCi4folder/FilmPhotoIntro.html. See also Campbell, Cinema Strikes Back: Radical Filmmaking in the United States, 1930-1942 (Ann Arbor, MI: UMI Research Press, I982). ment," in Communication and Class Struggle 2: Liberation and Socialism. An Anthology, ed. Armard Mitterlart and Seth Siegelaub (New York: International General, I983), I79.
} 
"truthful" content. They provided a new means of production. Shot on location by workers and with footage that had been cut and recut for multiple reels, the newsreels defined documentary film as a highly mediated construction. To quote Brody, "It is reality recorded on film strips and subjected to the painstaking technical operations, montage; whereby these strips are built up into wholes embodying our revolutionary interpretation of events. ${ }^{243}$ In I934 Brody was not only channeling Münzenberg. He was channeling Dziga Vertov, whose films were regularly screened at league events and served as league primers. ${ }^{44}$ Since the I920s, in, for example, his seminal 1929 film The Man with a Movie Camera, Vertov had subjected film to painstaking technical operations. His survey of the street life in Odessa and other Soviet cities displaced the authorial eye of the filmmaker with the work of the camera or kino-eye. Documentary, according to Vertov's neologism, did not declare war on fiction. It declared war on the integrated subject and narrative form dominating commercial productions..$^{45}$ It declared war on those who failed to recognize the ways in which new modes of production-the camera, the city, and the worker-liberated the individual for collective action.

Brody's appeal to the newsreel was at the center of Hurwitz and Steiner's 1935 essay and their decision to break with the league and develop Nykino (New York Kino), a new arm of radical film production in the United States. ${ }^{46}$ In opposition to Brody, Hurwitz and Steiner outlined an approach to filmmaking that called for the "theatricalization of human ideas and situations (mise-en-scène). ${ }^{.47}$ Theater, as Hurwitz insisted in an earlier essay titled "The Revolutionary Film—Next Step," could provide revolutionary workers with a less "fractional, atomic, and

43 Brody, “The Revolutionary Film-The Problem of Form," accessed November 28, 20II, http://www.ejumpcut.org/archive/onlinessays/JCi4folder/RevFilmForms.html. This essay first appeared in the February I934 edition of New Theatre.

44 English translations of Vertov's writings appeared in the Photo League's journal Filmfront. See Anthony Slade, ed., Filmfront-A Reprint Edition (Metuchen, NJ: Scarecrow Press, I986).

45 Annette Michelson, ed., Kino-Eye: The Writings of Dziga Vertov, trans. Kevin O'Brien (Berkeley: University of California Press, I984).

46 William Alexander discusses the formation of Nykino in Film on the Left: American Documentary Film from 1931 to 1942 (Princeton, NJ: Princeton University Press, 198I), 65-II2.

47 Steiner and Hurwitz, "New Approach," 303. 
incomplete form." ${ }^{48}$ Insisting that the league's creative comparison between frames could not sufficiently encapsulate working-class struggles or affect the audience for which they were intended, Hurwitz argued for "internal montage," which, as he explained, "is essentially a recreative analysis and reconstruction of an internally related visual element in terms of the shots of film." ${ }^{\prime 9}$ Hurwitz was surely watching and reading his Eisenstein. His critique of Brody was the same critique Eisenstein launched at Vertov in his I923 essay "The Montage of Attractions." Montage, Eisenstein insisted, required movement in shots or stills, not just between them. ${ }^{50}$ "It is not in fact phenomena that are compared," Eisenstein explained, "but chains of associations that are linked to a particular phenomenon in the mind of a particular audience." 51 Hurwitz turned to Eisenstein to develop his theory of "synoptic form” around Eisenstein's insistence that revolutionary film must do more than shock or, as he put it with reference to Vertov, "plough a tractor over the audience's psyche."52 "Even in documentary film," Hurwitz and Steiner concluded, "it is still necessary to use theatrical means of affecting an audience-suspense, build, dramatic line, etc." ${ }^{53}$

The turn to Eisenstein and theater was not a turn against documentary-or a return to Hollywood-style fiction and false consciousness. ${ }^{54}$ As Eisenstein argued in his examination of the development of cinema "through theater," the distinction between fact and fiction was a red herring. It followed from the distinction between film and theater along technological or, as Bazin would soon argue (with Eisenstein in mind), ontological lines. ${ }^{55}$ Internal or synoptic montage is not specific to film. It developed, as Devin Fore explains in his study of Eisenstein's I929 film The General Line, through Eisenstein's study of dramaturgical strategies. As Fore argues with reference to the most

48 Hurwitz, “The Revolutionary Film-Next Step," in The Documentary Tradition: From Nanook to Woodstock, ed. Lewis Jacobs (New York: Hopkinson \& Blake, I97I), 9I. The essay first appeared in the May I934 edition of New Theatre.

49 Hurwitz, "Revolutionary Film," 92.

50 Eisenstein, "Montage of Attractions," 29-34. See as well his "Beyond the Shot," in Taylor, ed., Eisenstein Reader.

5I Eisenstein, “The Montage of Film Attractions," in Taylor, ed., Eisenstein Reader, 36.

52 Eisenstein, quoted in Richard Taylor's introduction to Taylor, ed., Eisenstein Reader, 5.

53 Steiner and Hurwitz, "New Approach," 305.

54 For this reading, see Chris Robé, Left of Hollywood: Cinema, Modernism and the Emergence of U.S. Radical Film Culture (Austin: University of Texas Press, 2010), 128-30.

55 Bazin developed his media ontology through theater in his two-part essay "Cinema and Theatre," in Gray, What Is Cinema?, 76-124. 
famous shot in The General Line, the close-up of the peasant Marfa before the wonders of the cream separator, "The cinematic apparatus is absorbed into the figure on the screen, whose synthetic movements and expressions generate 'organic' equivalents for cinematic techniques such as editing and camera movement." ${ }^{56}$ Montage, in other words, does not take place on the editor's bench. It takes place in the actor's performance. It relies on, is produced through, the juxtaposition of actors' extreme emotional responses. Each still of The General Line, Fore concludes, was conceived of as a short film-one that takes place in the mind of the spectator, not on the screen. Eisenstein's theory of montage, as Roland Barthes famously argued in his I970 study of stills from Eisenstein's 1944 film Ivan the Terrible, asks us to think film beyond the film apparatus. "[T]he filmic," Barthes concluded, "cannot be grasped in projected film, the film 'in movement,' 'au naturel' but only, as yet, in the major artifact, which is the still." ${ }^{.57}$ Severing film's ontology from movement, Barthes disengaged the origin of film from naive conceptions of realism - and media. He also provided a definition of the document stripped of its preposition-a document of people, poverty, or class struggle. The fragment, the detail, or the film still does not refer; each moves the audience.

Eisenstein, as his response to The Wave made clear, differentiated film photography from still photography. Yet, that difference was not technological. It was manifest off screen and in theatrical effects programmed by the artist. In The Wave, Strand, like Eisenstein, looked to theater to revamp the limits of the atomic constructions of the documentary newsreel. This is evident in the film's scenario, which built its dramatic line around Miro's eventual murder at the hands of a smoothtalking politician and the fishermen's decision to carry out the strike. The Wave also engineered audience response through the very same technique Eisenstein had developed in his theory of internal montage: the juxtaposition of the actor's emotional reactions. In every pivotal scene of the film, Strand held the camera fixed and tight on an actor's

56 Devin Fore, "Jenseits der Einstellung, Hinter der Szene: Die Generallinie von Sergei Eisenstein," in Synchronisierung der Künste, ed. Robin Curtis, Gertrud Koch, and Marc Siegel (Munich: Fink Verlag, 20I2). I want to thank Fore for providing me with an English translation of this essay.

57 Roland Barthes, "The Third Meaning: Research Notes on Several Eisenstein Stills," in The Responsibility of Form: Critical Essays on Music, Art, and Representation, trans. Richard Howard (Berkeley: University of California Press, I99I), 59. 
countenance..$^{58}$ For example, in the film's opening scene, the dramatization of Miro's failure to make his living off the land, it is Miro's furrowed brow and grimace, not the portending storyline, that "speaks" to the audience. As Strasberg had instructed the members of Group Theatre, method performances abound in the Pavlovian recall to "genuine expressions," the subtle details, such as nuance of gesture, vocal inflection, and facial ticks..$^{59}$ If The Wave, as the reviewers remarked, was slow, sluggish, and not much more than a "photographic album," it was not because Strand failed to understand his new medium's "uniqueness of means." It was because, like the members of Nykino, with whom he eventually worked upon his return to New York in I935, he sought to develop a form of public address that responded to the social work of media.

The close-up, to be clear, is not a cinematic trope. Nor should we necessarily associate it with the silent era, and as a return of the human face as a means of communication following what the Hungarian film theorist Béla Balázs characterized as the atrophy of countenance on the printed page. ${ }^{60}$ As Eisenstein argued in his 1944 essay on the work of the so-called inventor of montage and the close-up, D. W. Griffith, the close-up found its origin in Griffith's obsession with Charles Dickens and Dickens's attention to detail. The opening line of Dickens's Cricket and the Hearth, "The kettle began it," was, according to Eisenstein, a close-up. ${ }^{61}$ Developing his argument about the importance of Griffith's films for the development of Soviet productions, Eisenstein explored the difference between Soviet and US camera work. For the Soviets, the close-up, Eisenstein noted, is not about distance-a quantitative measure of the camera's (and the viewer's) distance from the actor's face. It is a qualitative measure; it is a matter of proportion and emphasis. "We speak," Eisenstein wrote, "of a large talent, that is, one that stands out, by its significance, from the general line. ..." ${ }^{62}$ Said differently, it is not the face-resemblance and immediacy—that matters. It is the details

58 The film's cutting logs reveal a highly scripted orchestration of close-up, long-distance, and middle-distance shots around Miro's emotional reactions to his work. "The Wave, cutting logs," PSA/CCP, AG I7:28/2.

59 Counsell, Signs of Performance, 56.

6o Béla Balázs, Visible Man, reprinted in Béla Balázs: Early Film Theory, ed. Erica Carter, trans. Rodney Livingston (New York: Berghahn Books, 20I0). See Eisenstein's infamous response to Balázs, "Béla Forgets the Scissors," in Taylor, Eisenstein Reader, 67-72.

6I Eisenstein, "Dickens, Griffith and Film Today," I98-99.

62 Ibid., 238, emphasis in original. 
or, as Gilles Deleuze noted in his examination of Eisenstein's theory of internal montage, their deterritorialization beyond the shot. ${ }^{63}$ Turning to Dickens, Eisenstein deterritorialized media. He also dislocated the face from the representation of the worker, the human, and the individual. The turn to theater was meant to humanize the worker; yet, it was not the worker on the screen or only the worker's psychological development that mattered. It was the worker in the audience. The detailsMiro's grimace and brow, for example-moved the audience in a desired direction. In Mexico, Strand not only worked as a photographer and a filmmaker. He worked, like Eisenstein, as a propagandist and on the political potential of the camera's claims to objectivity.

\section{LIVING LABOR}

The Wave was not Strand's first attempt to interrogate the camera's claims to objectivity through a reconsideration of the representation of the human countenance. This problematic already framed the street portraits he produced in Lower Manhattan in I9I6. Attending to the camera's "unqualified objectivity," Strand attached a lateral viewfinder to his Ensign and shot the newspaper seller and sandwich man with the brass barrel directed at a right angle to his subjects. Strand's clandestine approach was a direct affront to the tradition of studio portraiture and what he once referred to as the "shibboleths of the time." It was assumed, Strand argued, that you need to know people, "wait for a moment when they are most alive and most themselves" to capture their likeness. ${ }^{64}$ Strand rejected this shibboleth. He was not interested in the person before the lens-the person's personal story, psychology, or likeness. He was interested in photography. Strand approached his subjects objectively in order to examine how the medium of photography called into question our assumptions about subjectivity. Significantly, Strand provided all of his portraits with the same generic title: Photograph-New York, 1917.

In I922, Strand returned to this investigation of the new relationship between man and machine in his now famous essay "Photography and the New God." Published in Broom, a journal originally printed in

63 Gilles Deleuze, Cinema 1: The Movement-Image, trans. Huge Tomlinson and Barbara Habberjam (Minneapolis: University of Minnesota Press, I996), 87-95.

64 Strand, quoted in Katherine Ware, "Photographs of Mexico, I940," in Stange, Paul Strand: Essays, Iog. 


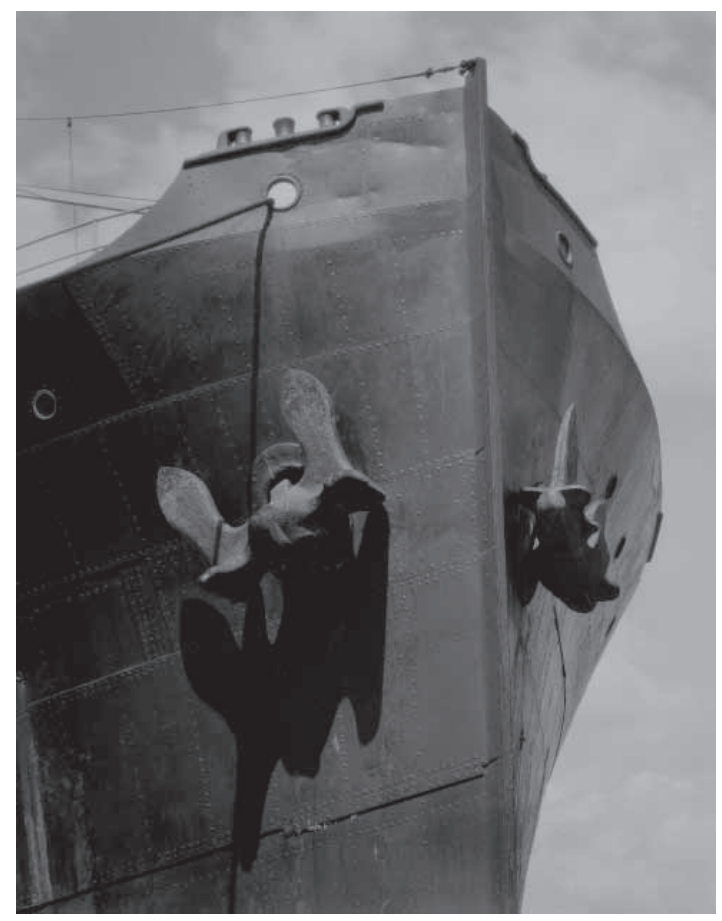

Rome and designed to introduce North Americans to the European avant-garde, the essay can be read as a pendant to Manhatta. In "Photography and the New God" Strand played the creativity of the Old Christian world, when men worked with their hands, against the monstrosities of the modern world, when machine-made hands "carry the burden of a thousand beasts and chained the power which was in the earth and water." ${ }^{65}$ As in the film, in the essay Strand questioned if our embrace of new technologies amounted to progress. Is man actively becoming dehumanized, Strand asked, at the supreme altar of the New God, the machine? Scenes from Manhatta certainly seem to offer some indication of Strand's conclusion. In the film, the camera's aerial approach and the city's monumental forms figuratively displace man. Men are present, represented as members of an amorphous and anonymous herd.

Strand, though, did not succumb to fears of a modern dystopia. The machine, he wrote, "must be humanized lest it in turn dehumanize us." ${ }^{\prime 6}$ In the film and the five photographs he published along with

65 Strand, "Photography and the New God," in Lyons, Photographers on Photography, I38. 66 Ibid., I43. 


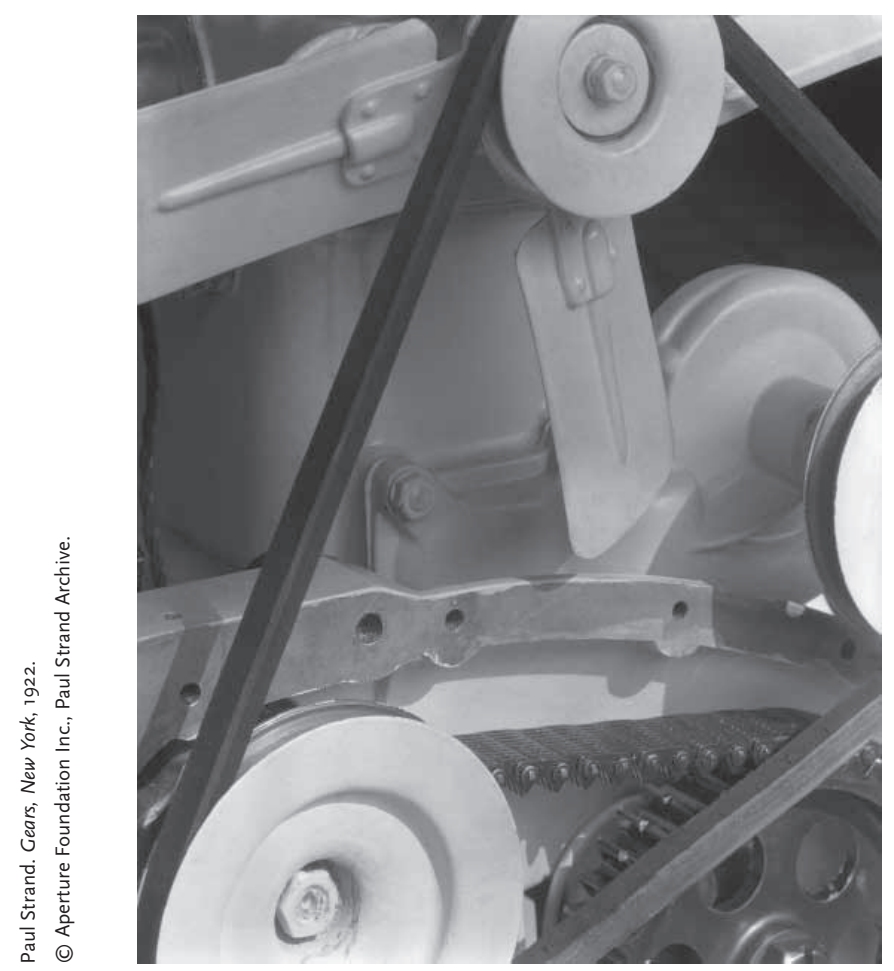

his essay, Strand played out representations of men dehumanized by the machine against the photographer's ability to use the camera creatively to humanize new technologies. On the pages of Broom, we see a freighter's hull from below and machine parts close-up and made strange. As in his I9ı6 portraits, in these photographs Strand investigated photographic means, not ends. He examined the machine, not simply the photographic image. Man, according to Strand, was neither the subject of nor subject to the machine. Man must use the machine objectively_and productively_as an "instrument of a new kind of vision." 67 This was photography's "uniqueness of means." Photography, as Strand explained in his I9I7 essay, had to be born of "actual living," adding, "In the same way the creators of our skyscrapers had to face the similar circumstance of no precedent, and it was through that very necessity of evolving a new form, both in architecture and photography that the resulting expression was vitalized." ${ }^{68}$ Surveying a range of machines, Strand conflated the organization of new forms with the negotiation of new ways of living. 
Given Strand's plea, it should come as no surprise that the photographs from this period are similar to those eventually produced by the champion of New Vision, Lázsló Moholy-Nagy. In the mid-I920s, Moholy-Nagy, too, sought to realign human vision in accordance with the machine in his own photographs of modernity's monumentsBerlin's radio towers and the clean lines of new domestic spaces. Moholy-Nagy's re-evaluation of the medium of photography was also published in Broom. The journal's fourth volume (March I923) included Moholy-Nagy's "Light-A Medium of Plastic Expression," which anticipated the thesis of his 1925 book Painting, Photography, Film. Thinking the three media together, Moholy-Nagy insisted that the emergence of new machines for seeing required questioning and historicizing photography's claims to objectivity. Photography, as the photograms Moholy-Nagy included along with his essay served to demonstrate, was a productive, not a reproductive, medium. ${ }^{69}$ Seeing with the machine, seeing straight, did not mean reproducing or literalizing the modern world and its fragmentation - the effects of photography. Seeing with the machine was a new form of labor.

Strand's analysis of "new" and "living" vision resonates with contemporary materialist theories about photography's productive capacities. In fact, his investigation of the relationship between man and machine in "Photography and the New God" was pitched to challenge our assumptions about the status of the artist working in a society paying unprecedented homage to industrialization and efficiency—or traditional nonart values. The modernist artist, Strand insisted, was not divorced from the social machine, a "waster and non-producer."70 "For he, who despite his social maladjustment," Strand explained, "has taken to himself with love a dead thing unwittingly contributed by the scientist, and through conscious use, is revealing a new and living act of vision." ${ }^{71}$ Furthering his charge that the artist can and must humanize the machine, Strand was not channeling Bell's call for significant forms and art's autonomy. He was exploring what Karl Marx had

69 Lázsló Moholy-Nagy, Painting, Photography, Film, trans. Janet Seligman (Cambridge, MA: MIT Press, I973), 29. Notably, Moholy-Nagy's book ends with an investigation of the medium of film through its relationship to other media-typographic forms and modern publicity. See as well Moholy-Nagy, "Production-Reproduction," in Photography in the Modern Era: European Documents and Critical Writings, 1913-1940, ed. Christopher Phillips (New York: Metropolitan Museum of Art and Aperture, 1989), 79-82.

70 Strand, "Photography and the New God," I39.

7 I Ibid. 
defined as the key to modernization: the dynamic relationship between dead things - commodities and new forms of production-and living labor. The dead thing or dead labor, Marx argued, is neither useless nor necessarily spent. It "lives," he explained, "sucking living labor, and lives the more, the more labor it sucks." " Man, in other words, neither masters the machine nor is mastered by it. He becomes a mechanical part incorporated into new systems of production. Strand's commitment to the camera's objectivity complicates our histories of his formalism; it also complicates the claim that Strand found politics in Mexico. Politics, as even Strand's earliest portraits make clear, is not represented in the frame, the ossified labor of the dead thing monumentalized and captured on film. It is produced through a belief in the productive potential of new technologies.

Summing up his account of the camera's re-evaluation as an instrument of a new and living vision, Strand, perhaps not surprisingly, turned his attention to portraiture. He took stock of the work of his first mentor, Stieglitz, and Stieglitz's decision to record his subjects through a series of photographs. A case in point here is Stieglitz's series on Georgia O'Keefe in which the "old master" recorded his muse through an accumulation of body parts and details. For Strand, Stieglitz's examination of his subject through disembodied forms was another example of throwing the shibboleths of photography and portraiture "out the window." Representing the subject as a sum of many parts, Stieglitz, at least according to Strand, developed portraiture into a means for engaging with the ways in which photography's promise of objectivity shifted the very conception of subjectivity and media. The machine does not trump the hand of man or what Stieglitz called photography's "hand work." It debunked existing values and conventions. Strand's insistence on this point is hard to miss. He summed up his analysis of Stieglitz's relative forms as follows: "In this sense portrait painting, already nearly a corpse, becomes an absurdity."73

Strand's suggestion that portrait painting was nearly dead, if not an absurdity, anticipates one of the most important debates in photographic culture in the 1920s. In I928, on the pages of the journal Novpi

\footnotetext{
72 Karl Marx, Capital: A Critique of Political Economy, vol. I, trans. Ben Fowkes (New York: Vintage Books, I976), 342 .

73 Strand, "Photography and the New God," I42.
} 
Lef, the Soviet writer and critic Ossip Brik too called for the end of the painted portrait. "We need a method," Brik explained, "whereby we can represent this individual persona not in isolation, but in connection with other people. In the visual arts it is the photograph that offers this technical possibility." ${ }^{74}$ Alexander Rodchenko famously seconded Brik's charge. Writing as well in I928, in the next issue of Novyi Lef, Rodchenko penned his manifesto "Against the Synthetic Portrait, for the Snapshot." Ridiculing the monumentalization of Lenin-the literal enlargement of his image-Rodchenko explained, "Crystallize man not by a single 'synthetic' portrait, but by a whole lot of snapshots taken from different times and in different conditions." 75 Brik and Rodchenko did not reject painting. They historicized technologies, rejecting, as Benjamin Buchloh argues, bourgeois conceptions of the subject as static, whole, or fixed. ${ }^{76}$ In a socialist society, Brik and Rodchenko explained, art must overcome bourgeois forms of commemoration and develop the possibilities for deontologizing the subject that were latent in new recording devices. This promise, Walter Benjamin explained in his I93I history of photography, was brilliantly captured in "the physiognomic gallery mounted by Eisenstein or Pudovkin." ${ }^{\prime 7}$ Soviet films, Benjamin noted, provided "the first opportunity in decades to put before the camera people who had no use for their photographs." 78 Benjamin too ignored the technical differences between film and photography.

Drawing Strand into these debates might seem far-fetched. After all, Strand never paid homage to the snapshot. In fact, he remained dedicated to limited editions and hand-pulled photogravures, like the portfolio of photographs from Mexico he published in I940. Strand

Ossip Brik, "From Painting to Photography," in Phillips, ed., Photography in the Modern Era, 23I.

75 Alexander Rodchenko, "Against the Synthetic Portrait, for the Snapshot," in Phillips, ed., Photography in the Modern Era, 242.

76 Benjamin H. D. Buchloh, "Residual Resemblance: Three Notes on the Ends of Portraiture," in Face-Off: The Portrait in Recent Art, ed. Melissa E. Feldman (Philadelphia: ICA, I994), 55-58.

77 Walter Benjamin, "A Little History of Photography," in Walter Benjamin: Selected Writings, vol. 2, pt. 2, ed. Michael Jennings, Gary Smith, and Howard Eiland (Cambridge, MA: Harvard University Press, 2005), 520. It is worth noting that Benjamin's attention to the significance of the face was inseparable from his investigation of photography's promise to bring things "close" and illuminate "details." Benjamin, "Little History," 519. 
also made these portraits of Mexico's peasants with a lateral viewfinder attached to his camera. Strand never rejected the formal values of the fine art print. In all of his work, he privileged the creative possibilities of the camera. Holding onto artistic skill was perhaps a gamble. It may just have been the limits of Strand's photography. Yet, it also presented an investigation of media beyond ontology. For Strand and a range of photographers and filmmakers working through the challenges new recording devices posed to the representation of people from "below"the sandwich man, the newspaper seller, and the peasant-it was the machine — not the subject—-that needed to be humanized. These subjects after all had no use for traditional portraits.

\section{PRIMITIVE FILM}

If Mexico became the battleground for Strand's investigation of the limits of the camera's objectivity, the photographic portrait, and representations of people from below, how are we to account for Strand's close-up shots of seminude bodies of men at work? It is hard to ignore the fact that Strand's "romance of revolution" was figured through the representation of what the anthropologist Stuart Chase called "machineless men" and what others might simply call primitivism. ${ }^{79}$ Why, in other words, did he stage his history of modernization, his reevaluation of the relationship between man and modern forms of production, around the classic tale of man versus nature? Strand's model here was not Eisenstein. It was the so-called "father of documentary film," Robert Flaherty. Named as such by John Grierson, the Scottish filmmaker who coined the term documentary in I926, Flaherty established-at least according to Grierson-the principles of documentary film around his recordings of the actualities of everyday life in nonindustrialized cultures. ${ }^{80}$ In Mexico, Strand discussed Flaherty's work at length, remarking in his "Note" that Flaherty's I922 film Nanook of the North offered an "immense gift for contact with primitive peoples and for creating or finding the elemental drama in their

\footnotetext{
79 Stuart Chase, Mexico: A Study of Two Americas (New York: Literary Guild, I93I). Rohrbach notes that Strand read Chase's book before his trip to Mexico. See Rohrbach, "Art for Society's Sake," iाI.

$80 \quad J o h n$ Grierson, "Flaherty's Poetic Moana," in Grierson on the Movies, ed. Forsyth Hardy (London: Faber and Faber, I98I), 23-25. See also Grierson's I932 essay, "First Principles of Documentary," in Grierson on Documentary, ed. Forsyth Hardy (London: Collins, I946), 78-89.
} 
lives." ${ }^{11}$ Notably, Eisenstein too claimed this lineage. "We Russians," Eisenstein admitted, "learned more from Nanook than any other foreign film. We wore it out studying it. That was in a way our beginning." ${ }^{2}$ It was not only Griffith's invention of parallel montage that shaped Soviet documentary work. It was Flaherty's commitment to develop a form of film that rejected the Hollywood system: studio productions and professional actors.

Flaherty's films were hardly unanimously praised, and certainly not by the members of the Film and Photo League and Nykino. Countless critics - in particular, those associated with New Theatrelaunched vitriolic attacks on Flaherty's work, insisting that his films ignored history and the "actualities" of British imperialism. ${ }^{83}$ In Nanook of the North, moviegoers did not witness contemporary Inuit life. They indulged Flaherty's portrayal of Nanook, the "noble savage," living outside of time and beyond history. As one member of the league wrote in his review of Flaherty's fishing film Man of Aran (I934), the "novel task" of filming the working class has resulted in nothing more than the circulation of vapid social types: "a cog, a peasant like creature, a person at the mercy of the elements, a down-and-outer with comic possibilities, or a boor." ${ }^{84}$ Strand joined this chorus of criticism. Chiding Flaherty for his insistence on allegorizing social struggles through man's relation to nature-as opposed to man's relationship to man-Strand assailed Flaherty's films as follows: "In a world in which human exploitation is so general it seems to me a further exploitation of people, however picturesque, different and interesting to us they may appear, to merely make use of them as material." 85

The closing sequence of Man of Aran, which begins with a close-up of a peasant at the "mercy of the elements," neatly demonstrated Strand's critique. As the film draws to a close, the father and fisherman Coleman "Tiger" King turns and looks out to sea. His face, chin

8I Strand, quoted in Rohrbach, “Art for Society's Sake," II9. The film's contemporary reviewers also noted this lineage. See, for example, Robert Stebbins, "Paul Strand's Mexican Film Redes (1935)," in Kline, New Theatre and Film, 316-20. The review was published in the journal's November I936 edition.

82 Cited in Paul Rotha, Robert Flaherty: A Biography, ed. Jay Ruby (Philadelphia: University of Pennsylvania Press, I983), I57.

83 See, for example, Irving Lerner's review, "Robert Flaherty's Escape," reprinted in Kline, New Theatre and Film, 307-Io. Lerner was a member of Nykino. Notably, Grierson also accused Flaherty of "escapism." See his "First Principles of Documentary," 8I.

84 E. K., "The Films That Look at Workers," in Slade, Filmfront, 20-22.

85 Strand, quoted in Alexander, Film on the Left, 7I. 
pointed up and at an angle, fills the film frame. Flaherty holds the shot momentarily before zooming out to reveal King's family, his wife and son. He holds the shot once more and zooms out again. The family, now in full view, turns parallel to the frame and walks along the coast toward the horizon. Their movement is intercut with middle-distance shots of mammoth waves crashing against the craggy shore. In the final moments, Flaherty zooms out again. The family, as if exiting the scene, loses dimension before the sea's surge. They are blacked out, silhouetted against the horizon and the film frame. The sea, Flaherty's camera suggests, strips the fisherman and his family of detail, character, and class. Man in Man of Aran is nothing. He is displaced, quite literally, by nature. He is made over as form.

The Wave certainly corrected what Strand saw as the limits of a Flaherty film. Following Clurman's instructions, Strand socialized labor and the means of production. Yet, Strand's insistence that Flaherty turned people into material, into icons, suggests that he was not merely critical of Flaherty's allegorical storylines. He was critical of Flaherty's camera work. What was unique about Flaherty's films, as his biographers have noted, was that Flaherty never thought it necessary to

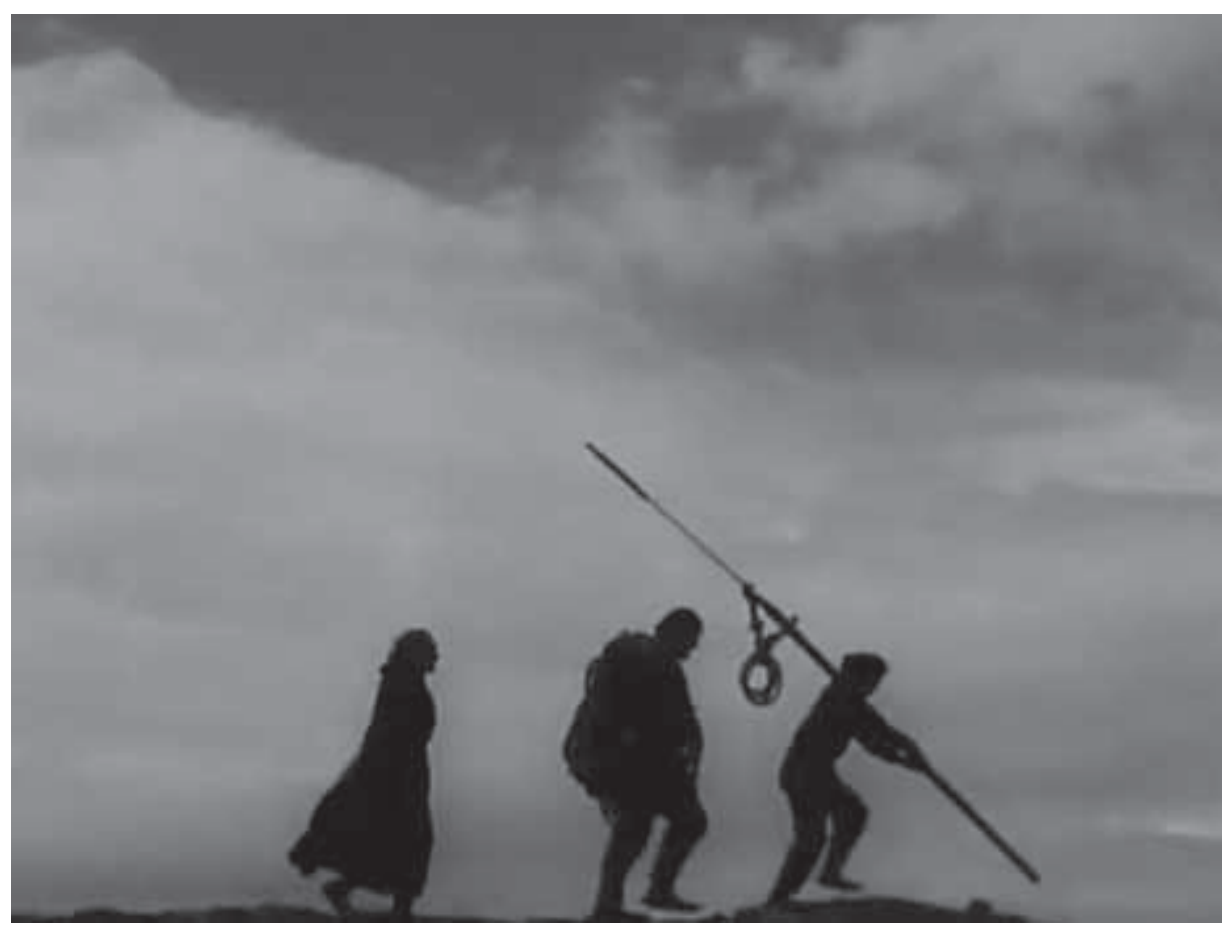


edit them. As the editor begrudgingly hired for Man of Aran explained, "Flaherty's actual film-making took place not in the camera, not on the cutting bench, but in the projection room." ${ }^{86}$ Flaherty's films were designed to make images move. Significantly, Bazin championed this aspect of Flaherty's work. The organization of his media ontology pitted Flaherty's long takes against Eisenstein's “language of syntactical units. ${ }^{187}$ Condemning Eisenstein (and ignoring his genealogy), Bazin saw Flaherty's camera work as a reflection of his respect for the essence of film: the reproduction of the unity of space and the contiguity of cinema beyond the frame. ${ }^{88}$ Strand would have most likely agreed, though Flaherty's respect for spatial contiguity led him to a much different assessment of the films and the "essence" of cinema. For Strand,

Flaherty's films did not—or did not merely—primitivize his subjects. They primitivized the audience. His long unedited takes naturalized seeing.

Strand rejected Flaherty's primitivism by rejecting a film form that failed to take seriously the camera's role as a new instrument of vision. This critique of Flaherty's humanism is most evident in the film's pivotal scene, when Miro gathers the fisherman on the dunes to call for strike action. Standing before a crowd of fishermen, Miro raises his fist in the air and expounds on capital's social logic- "poverty is not the fault of nature, nor God's Law." Miro's message is corroborated by his gesture; his closed fist and raised arm are iconic signs of working-class consciousness. This message is also made evident through the film. Miro's speech is intercut with clips showcasing the transformation of labor into capital. The film moves from short sequences of cattle and

86 John Goodman, quoted in Rotha, Robert Flaherty, I29.

87 Bazin, "The Evolution of the Language of Cinema," in Gray, What Is Cinema?, 26-28.

88 Bazin, "The Virtues and Limitations of Montage," in Gray, What Is Cinema?, 46. 
men at work in the fields to abstracted machine parts reminiscent of Strand's I922 still studies of gears through the arrival of goods on the market. We see, in short, the relationship between living and dead labor. The Wave certainly eschewed modern forms of production-factories and industrialization. Yet, the film did not suggest that those laboring on the land are outside time or outside industry. This is not simply because Miro's speech mechanizes nature around the capitalist system of accumulation. It is because the film's drama is illustrated filmically. History is displaced from the subject and the singular portrait to the machine, the film. Working-class subjects are not finally represented, heroicized, and dignified. They are finally socializedthrough film-in the mind of the viewer. Film is made legible to the audience as a means of socialization.

In Mexico, Strand worked as a bureaucrat and on portraiture. Through film, he carved out a mode of representation for those "no longer in need of traditional portraits." His subjects neither posed for his camera nor were monumentalized on film. They were neither before the camera nor on the screen. Strand, like many working on the political potential of mass media, sought to eradicate that boundary. He dislocated the subject from the still, and the document from its preposition-records of poverty and work. Strand's work, in turn, tests our own shibboleths about the relationship between media and modernism. Media are not hardware, recording devices and extensions of man. They are, like his portraits, social machines. They historicize desire and make people move.

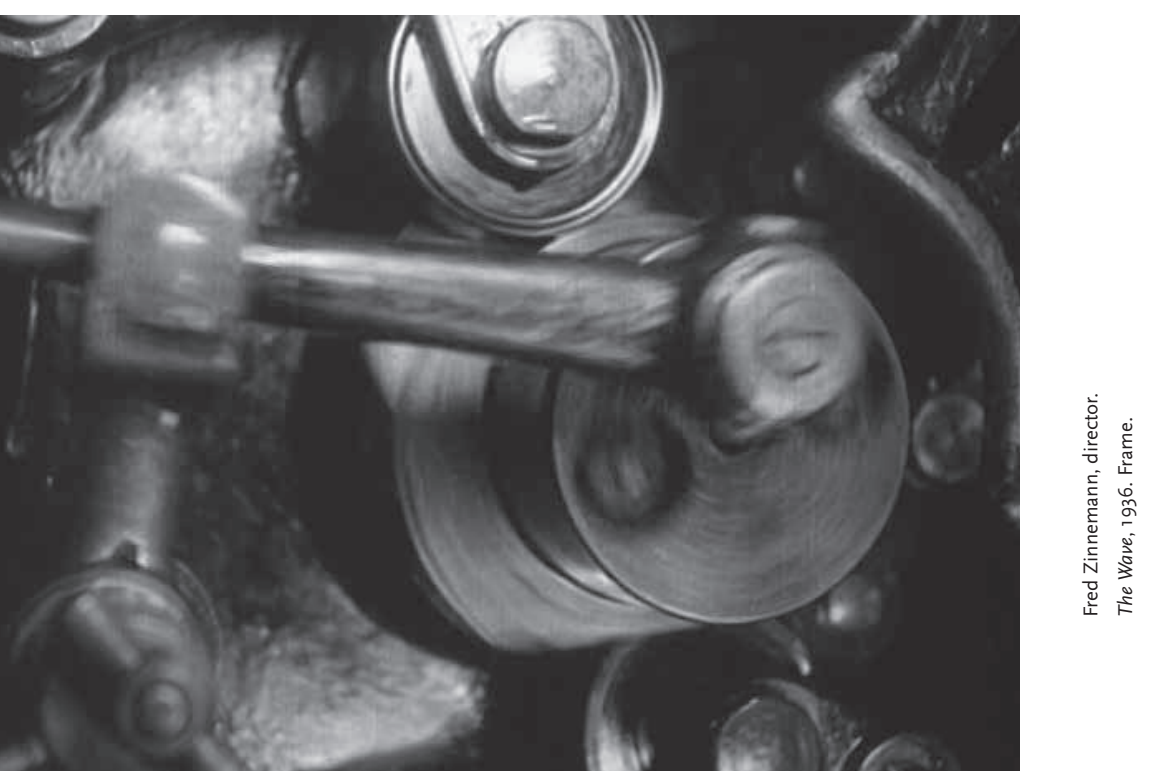

